\title{
Assessment of Groundwater Vulnerability in Northern Babylon Governorate, Iraq
}

\author{
Qais Al-Madhlom1, Nadhir Al-Ansari1, Hussain M. Hussain'² \\ ${ }^{1}$ Civil, Environmental and Natural Resources Engineering, Lulea University of Technology, Lulea, Sweden \\ ${ }^{2}$ Department of Geology, College of Science, Kufa University, Najaf, Iraq \\ Email: qais.al-madhlom@ltu.se, nadhir.alansari@ltu.se, hussainm.alshimmary@uokufa.edu.iq
}

How to cite this paper: Al-Madhlom, Q., Al-Ansari, N. and Hussain, H.M. (2016) Assessment of Groundwater Vulnerability in Northern Babylon Governorate, Iraq. Engineering, 8, 883-902.

http://dx.doi.org/10.4236/eng.2016.812080

Received: December 7, 2016

Accepted: December 24, 2016

Published: December 27, 2016

Copyright $\odot 2016$ by authors and Scientific Research Publishing Inc. This work is licensed under the Creative Commons Attribution International License (CC BY 4.0).

http://creativecommons.org/licenses/by/4.0/

\begin{abstract}
Groundwater is one of the main resources from the earth, especially for arid or semiarid countries. For this reason, it is very important to keep it unpolluted. Drastic Model is one of the widely used models to detect groundwater vulnerability to the contaminants that are found on ground surface. In this model, it is assumed that the vulnerability of the groundwater is affected by seven hydrological parameters. They are: depth from the surface ground to groundwater, net recharge into the aquifer from the surface, aquifer media, soil media, area topography, impact of vadose zone and aquifer hydraulic conductivity. In this study, the DRASTIC model was applied on the northern part of Babylon governorate in Iraq, to predict the vulnerability of Groundwater in that area. The results indicate that the vulnerability is very low to low grade.
\end{abstract}

\section{Keywords}

Groundwater Vulnerability, Groundwater Sensitivity, DRASTIC Model, GIS, Babylon, Iraq

\section{Introduction}

In the last decades, big developments took place in all fields of knowledge and industry with intensive attention on investment of all available resources to get the maximum benefit with minimum cost and minimum side effects on the environment.

Groundwater is one of the main water resources on the earth [1] [2], especially for arid and semi-arid countries for two reasons. The first is the scarcity of both surface water, and the second is the relatively low susceptibility of groundwater to pollution [3]. After the industrial revolution the world witnessed many changes due to the global warming as a result of the large development in industry. Consequently, many countries 
were affected and became arid or semi-arid. Middle East and North Africa countries are on the top of the affected countries. Some studies highlighted the size of the problem by comparing the annual water share for each person. For Iraq, it was found that the share reached about $6029\left(\mathrm{~m}^{3} /\right.$ capita·year $)$ during 1995, and it was expected to be 2100 $\left(\mathrm{m}^{3} /\right.$ capita·year $)$ in 2015 [4].

Recent work indicates that Iraq is facing water crises problems and its water resources are declining due to climate change and building of dams upstream the Tigris and Euphrates rivers [5]-[14]. Due to this fact, Iraq will be depending more on its groundwater resources. Since groundwater is threatened to be contaminated due to natural reasons or different human activities (e.g. residential, industrial, agricultural activities municipal and commercial) [15], in addition for the fact that water quality is an effective measure for human welfare [16], then it becomes very important to study the groundwater potential to be contaminated and try to avoid contamination hazards.

There are two types of vulnerability intrinsic and specific vulnerability. Intrinsic vulnerability may be defined as how much easy for the contaminant that is found on the surface ground to be carried by the infiltrated water and diffused in to the groundwater [17] [18], while the specific vulnerability could be defined as the ability of a specific contaminant or a group of contaminants to be transported by the infiltrated water and diffuses in groundwater [17] [19].

Some researchers studied the vulnerability of groundwater in various parts of Iraq [20] [22], but none of them studied the groundwater conditions in Babylon Governorate. The groundwater in this area is relatively shallow and can be easily contaminated. For this reason this research was performed to see the vulnerability of groundwater to be polluted in the northern part of Babylon Governorate. This can help decision makers for putting prudent management planning for the groundwater resources in this governorate.

\section{Study Area}

\subsection{Location}

The studied area represents the north part of Babylon governorate, the famous ancient city which is located in the middle part of Iraq about $100 \mathrm{~km}$ south of the capital Baghdad (Figure 1). It is bounded between longitudes ( $44^{\circ} 2^{\prime} 42.245^{\prime \prime} \mathrm{E}$ and $\left.45^{\circ} 2^{\prime} 2.964^{\prime \prime} \mathrm{E}\right)$ and latitudes $\left(32^{\circ} 25^{\prime} 55.287^{\prime \prime} \mathrm{N}\right.$ and $\left.33^{\circ} 7^{\prime} 34.229^{\prime \prime} \mathrm{N}\right)$ (Figure 1). The study area includes the two northern administrative units from the five units of Babylon governorate, which are Al-Musayyab Qadhaa' and Al-Mahawil Qadhaa' (Figure 1) covering an area of about $2794 \mathrm{~km}^{2}$. Its population is about 710832 capita [23]. It is bordered by Baghdad from the north, Wasit from the east, Karbala and Anbar from the west, and the southern part of Babylon from the south (Figure 1). The Euphrates River flows through this area for about $52 \mathrm{~km}$ (with $34 \mathrm{~km}$ before the Hindyia barrage which controls Euphrates flow into the downstream water courses: Euphrates, Shatt Al-Hilla, Kifil, Hussainina, Beni Hassan), and Tigris River flows for a distance of about $112 \mathrm{~km}$ about $20 \mathrm{~km}$ to the east of this area. 


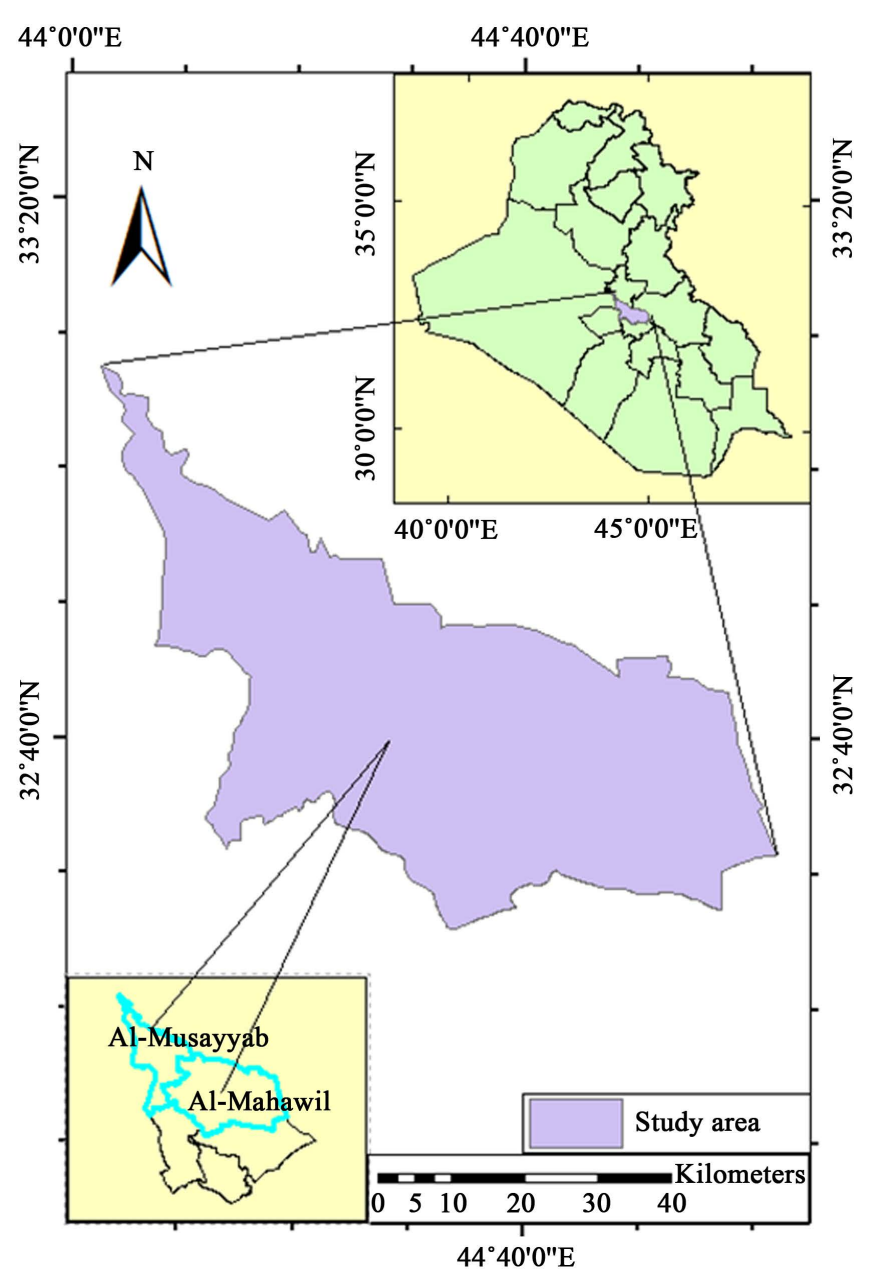

Figure 1. Study area.

The study area forms $2.4 \%$ of the Mesopotamia plain (Figure 2) which covers an area of about $116,000 \mathrm{~km}^{2}$ [24]. The general topography of this area is characterized by its imperceptible gradient from northwest to the southeast. Where the highest point in this area is about 62 meter above sea level (m.a.s.l.) in its northern part, and the lowest point is about 21 (m.a.s.l.) in its southern part. This coincide with the slope of Mesopotamia Plain, where its highest point is 140 (m.a.s.l.), in Fatha vicinity in the north, whereas its lowest point is about 1 (m.a.s.l.), in the extreme southeastern margin along the Gulf [24].

Generally, the soil in this area is alluvial fluvial silty clayey loam similar to the whole Mesopotamia Plain soil, where its origin is the fluvial deposition from Euphrates and Tigris Rivers. The climate of this area is arid or semiarid. It is extremely hot in summer, mild winter and short transition seasons of spring and autumn. The mean annual rainfall ranges between $200 \mathrm{~mm}$ to $125 \mathrm{~mm}$ from the north to the south, and the average annual evaporation from this area coincide with the general evaporation range for the Mesopotamia Plain which is $2600 \mathrm{~mm}$ in the northern parts to $3250 \mathrm{~mm}$ in the southern parts (Figure 2) [24]. 


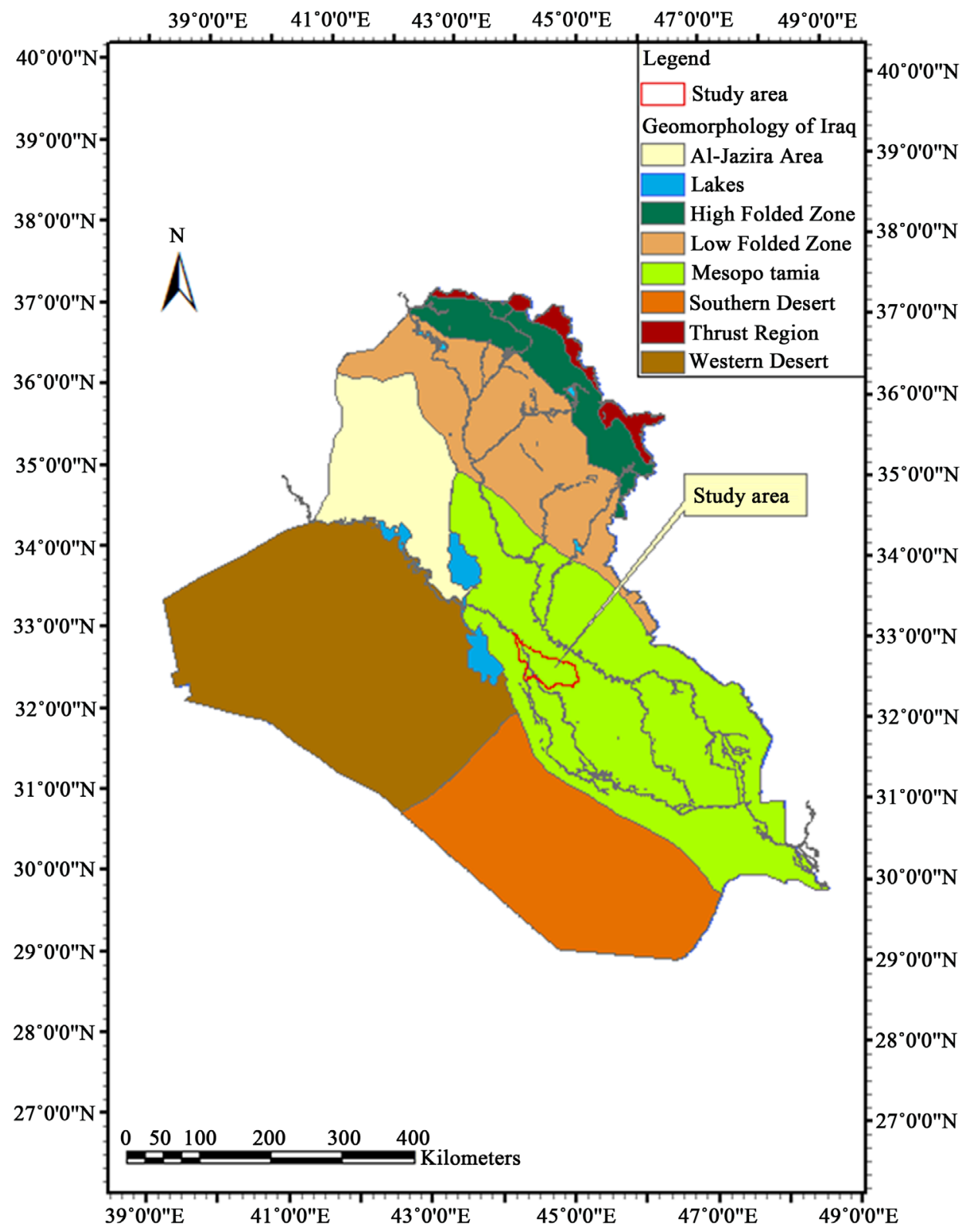

Figure 2. Location of the study area within the Mesopotamia plain [27].

The stratigraphy of the Mesopotamian region was summarized by Yacoub [25]. The sequence of deposits can be summarized as follow (Figure 3).

1) Pliocene-Early Pleistocene Rock Units: These are represented by Bai Hassan Formation, Dibdibba Formation, Mahmudiya Formation. Bai Hassan is the formation that is found in the studied area, where the other formations are located in other locations in the Mesopotamia Plain.

2) Pleistocene Sediments (Rock Units): These are sediments of the Mesopotamia Fluvial Basin, alluvial fan sediments, and river terraces (Figure 4). The study area contains fluvial sediments and some of river terraces. 


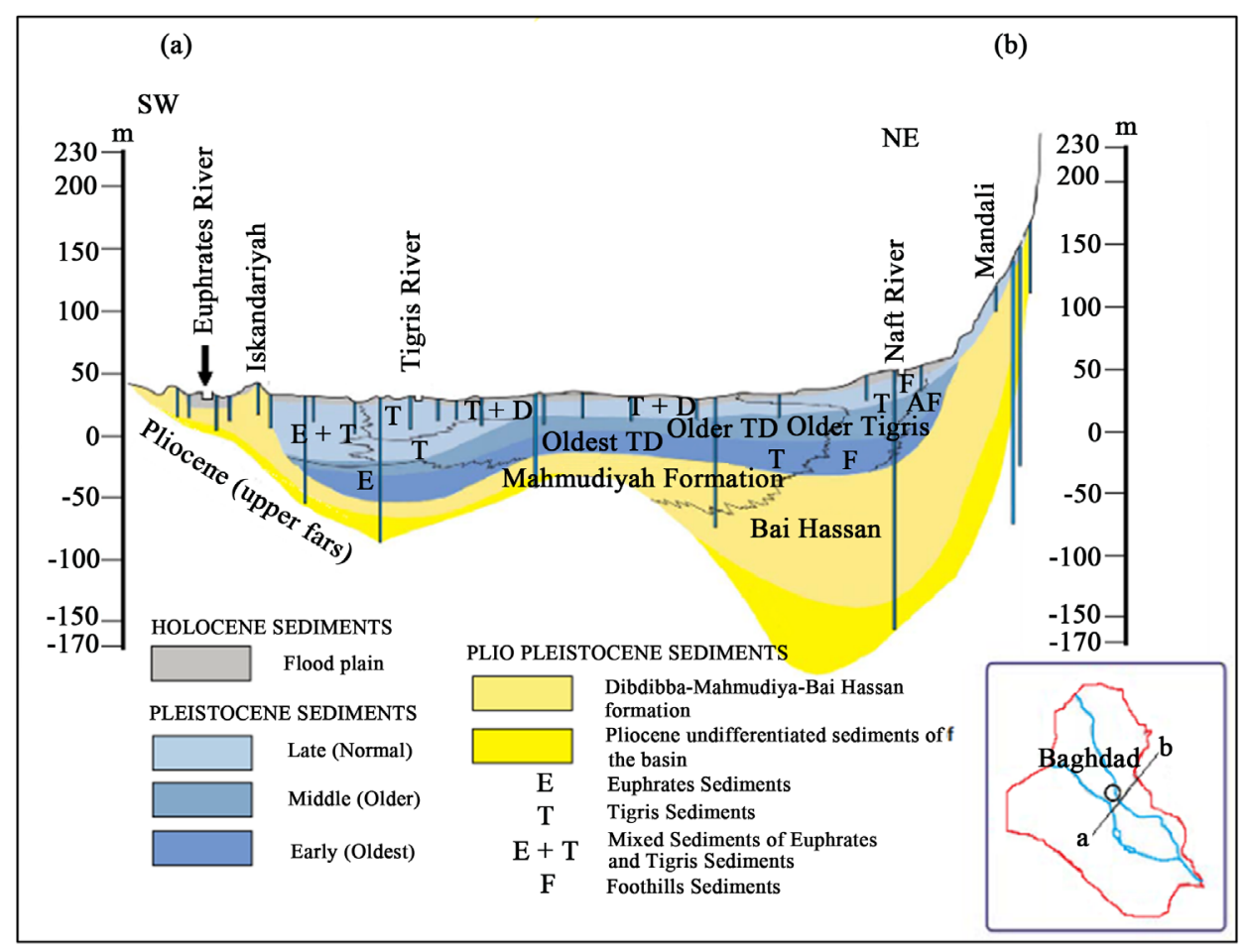

Figure 3. Subsurface geological cross section between Iskandariyah-Mandali, Northern Mesopotamia plain [25].

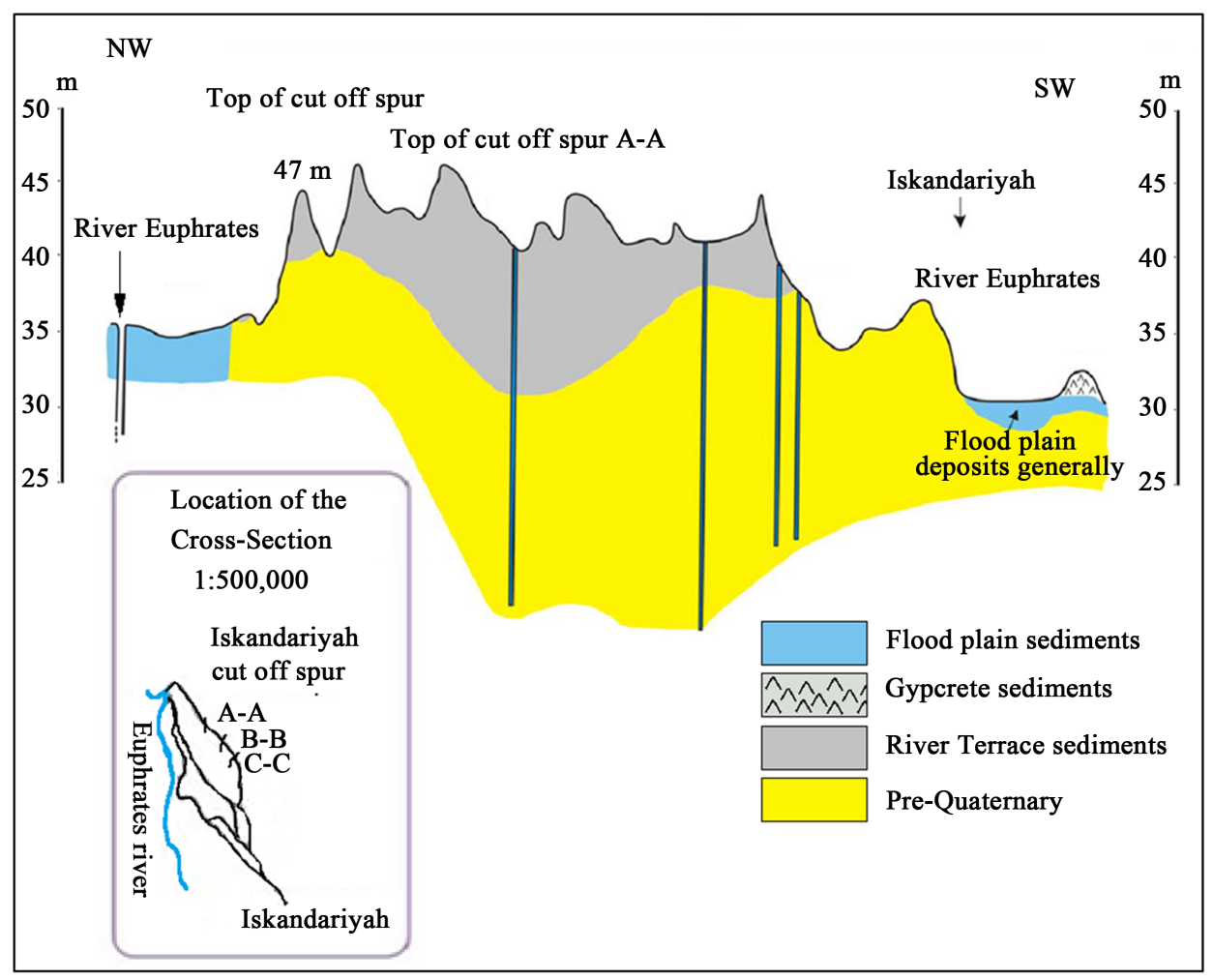

Figure 4. Euphrates river terraces in the vicinity of Iskandariyah after [25]. 
3) Pleistocene-Holocene Sequence: These are Sheet Run-off sediments, slope sediments, and gypcrete. This type of sediment is not observed in the study area.

4) Holocene Sequence: This is the existing sedimentary environment. This type of sediments covers the majority of Mesopotamia plain (Figure 5). They make the upper part (about $15-20 \mathrm{~m}$ ) of the Quaternary sediments of the Mesopotamia Basin. The Holocene sequence contains different types like fluvial, deltaic, lacustrine and estuarine/marine units. But the types that cover the study area are mostly flood plain of Euphrates and Tigris Rivers, some Aeolian sediment exists in the north and south of the studied area. There are some areas in the north of the studied area having exposures of Bai Hassan formation, which represents Pliocene-Early Pleistocene sediments (Figure 5). The depth of Quaternary deposits (Pleistocene deposits and Holocene deposits) reaches in some sites up to $100 \mathrm{~m}$ (see Figure 3).

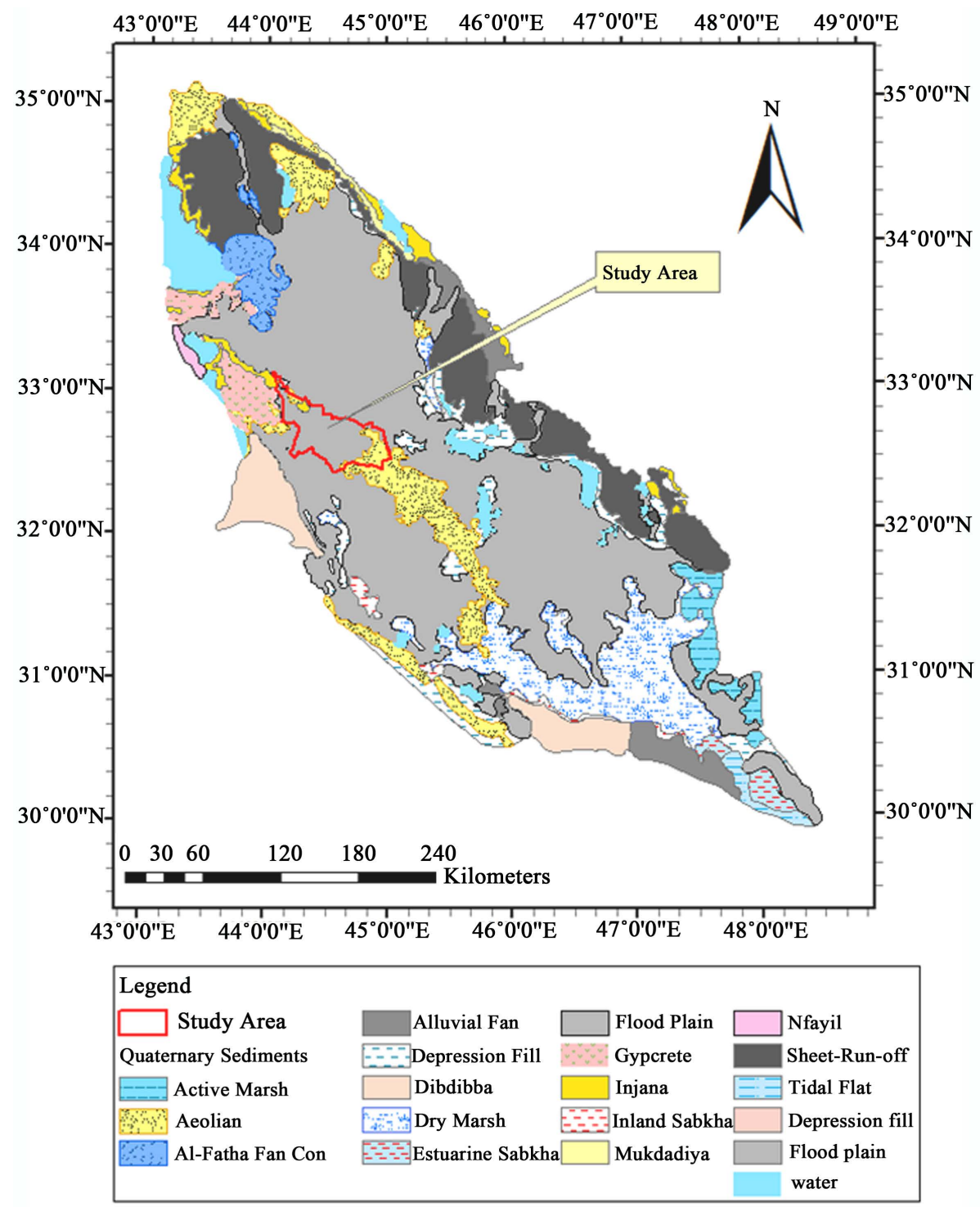

Figure 5. Geological map of the Mesopotamia plain [25]. 
The aquifer-aquitard in Mesopotamia Plain is considered lithological complex aquifer system [26]. This is due to the fact that there are abrupt lithological changes in the Mesopotamian plan which affects the hydrogeological properties. These effects represented by the heterogeneous lithification (laterally and vertically) on the sediments which lead to heterogeneous hydraulic conductivity in the plain, consequently difficulty in aquifer-aquitard delineation.

\subsection{Population and Water Use}

The population of the study area is 710,832 . The major cities cover an area of $32.12 \mathrm{~km}^{2}$ with a population density greater than $5000\left(\right.$ capita $\left./ \mathrm{km}^{2}\right)$, and the remainder of the area $\left(2691 \mathrm{~km}^{2}\right.$ ) has population density less than that (see Figure 6).

The main share of the used water in this area is consumed in the agriculture purposes with the fact of presence about $2961 \mathrm{~km}^{2}$ arable area.

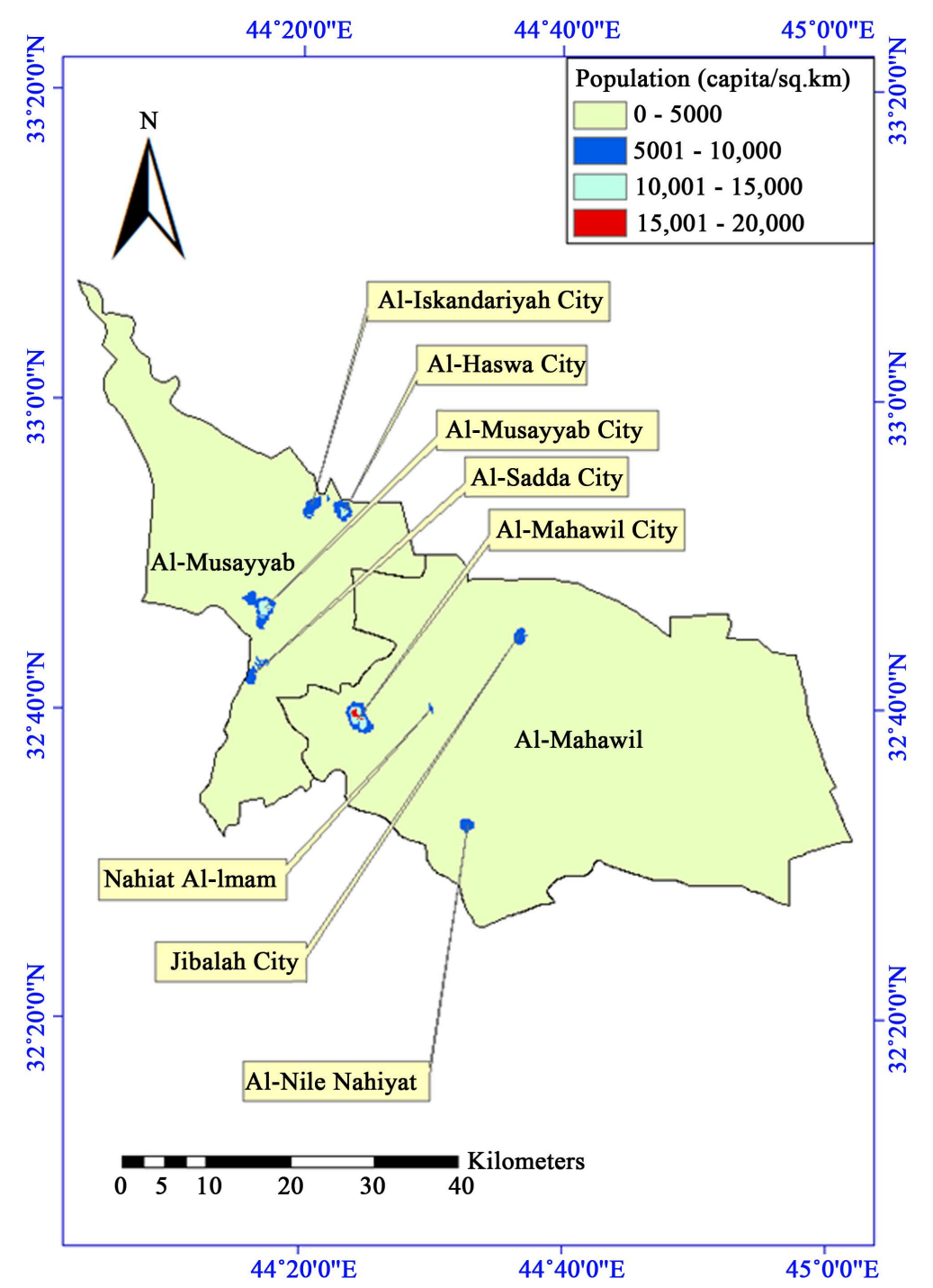

Figure 6. North Babylon population distribution. 


\subsection{Hydrology of the Mesopotamia Plain}

The groundwater piezometric level for the plain is based on the assumption of the hydraulic continuity within the entire Quaternary aquifer system. This means that all the aquifers in the plain are in a hydraulic continuity, which depends on the degree of lithification. Furthermore, there are two more facts related to the hydrogeological conditions in the sedimentary plain. The first is the hydraulic continuity between the aquifer complex system and the rivers in the plain and the second is the hydraulic continuity between the aquifer system and the deep formation underlying the fluvial deposits. Thus, depending on these assumptions the water table can be drawn in Mesopotamia Plain [26].

\section{Methodology}

In this study the DRASTIC model with the aid of GIS program was used to evaluate the intrinsic vulnerability of the aquifer of the study area [28] [29]. DRASTIC model was first developed by the United State Environmental Protection Agency (EPA) for evaluating the groundwater pollution potential [30] [31] [32], and during the last years it was widely used [33], because it gives a good indication for the groundwater sensitivity for the contaminants, and it is easy to get the required information for application of this model on groundwater [2].

The concept of DRASTIC model is that groundwater is affected by the contaminants that are carried by infiltrated water from the surface of the ground. In this model the contaminants are assumed to be on the ground surface, they are flushed into the groundwater by precipitation, and they have the mobility of the water [31].

According to DRASTIC model, the intrinsic vulnerability of the aquifer is affected by seven geological, hydrological parameters. These can cause changes of the groundwater quality of the aquifer [30]. The seven parameters are collected in the acronym DRASTIC which refers to: (D) depth to groundwater (which means depth from the ground surface to the water table), (R) net recharge, (A) aquifer media, (S) soil media, (T) topography, (I) impact of vadose zone media, and (C) hydraulic conductivity of the aquifer [30] [32].

In DRASTIC model each parameter has two values the first value is the rating value and the second is the weighting value. The rating value for each parameter ranges from 1 to 10 depending on the different effects of the variable types of that parameter on the vulnerability of the aquifer. The weighting value of each parameter is a constant value in the model, i.e. it will be constant for different rating values of that parameter.

The parameter weight value depends on the potential effect of that parameter on the groundwater vulnerability. Table 1 and Table 2 show the weight values with a brief description for each parameter and how it affects the vulnerability of the aquifer and the rating values for different cases for each parameter can be seen respectively.

DRASTIC index is the output of the DRASTIC model, which represents the vulnerability index of the groundwater, i.e. the higher DRASTIC index the greater chance for the groundwater to be affected by the pollution of the contaminants. The DRASTIC 
Table 1. Assigned weight for DRASTIC parameters [32].

\begin{tabular}{|c|c|c|}
\hline $\begin{array}{l}\text { Factors/hydrological } \\
\text { settings }\end{array}$ & Description & Relative weights \\
\hline Depth to water & $\begin{array}{l}\text { It is depth from ground to water table, deeper } \\
\text { the water table lesser will be the chances of } \\
\text { pollutants to interact with groundwater. }\end{array}$ & 5 \\
\hline Net Recharge & $\begin{array}{l}\text { It is the amount of water/unit area of land that penetrates } \\
\text { the ground surface and reaches the water table, it is the } \\
\text { reporting agents for pollutants to the groundwater. }\end{array}$ & 4 \\
\hline Aquifer media & $\begin{array}{l}\text { It is the potential area for water storage, the contaminant } \\
\text { attenuation of aquifer depends on the amount and } \\
\text { sorting of fine grains, lower the grain size higher the } \\
\text { attenuation capacity of aquifer media. }\end{array}$ & 3 \\
\hline Soil media & $\begin{array}{l}\text { Soil media is the uppermost and weathered part of } \\
\text { the ground, soil cover characteristics influence the } \\
\text { surface and downward movement of contaminants. }\end{array}$ & 2 \\
\hline Topography & $\begin{array}{l}\text { it refers to slope or steepness, areas with low slope } \\
\text { tend to retain water for longer, this allows a greater } \\
\text { infiltration of recharge of water and a greater potential } \\
\text { for contaminant migration and vulnerable to ground } \\
\text { water contamination and vice versa. }\end{array}$ & 1 \\
\hline Impact of vadose zone & $\begin{array}{l}\text { It is the ground portion found between the aquifer and the } \\
\text { soil cover in which pores or joints are unsaturated, } \\
\text { its influence on aquifer pollution potential similar to } \\
\text { that of soil cover, depending on its permeability, } \\
\text { and on the attenuation characteristics of the media. }\end{array}$ & 5 \\
\hline Hydraulic Conductivity & $\begin{array}{l}\text { It refers to the ability of the aquifer formation to } \\
\text { transmit water; an aquifer with high conductivity is } \\
\text { vulnerable to substantial contamination as a plume of } \\
\text { contamination can move easily through the aquifer. }\end{array}$ & 3 \\
\hline
\end{tabular}

Table 2. DRASTIC parameters and their rating scale [30].

\begin{tabular}{ccccc}
\hline Parameters & $\begin{array}{c}\text { Weight } \\
\text { scale }(\mathrm{w})\end{array}$ & Range & Rating $(\mathrm{r})$ & $\begin{array}{c}\text { Index scale } \\
(\mathrm{r} * \mathrm{w})\end{array}$ \\
\hline & & $0-1.5$ & 10 & 50 \\
& $1.5-4.5$ & 9 & 45 \\
Depth to the & $5.5-9.1$ & 7 & 35 \\
water table (m) & 5 & $9.1-15.2$ & 5 & 25 \\
& & $15.2-22.9$ & 3 & 15 \\
& $22.9-30.5$ & 2 & 10 \\
& & $>30.5$ & 1 & 5 \\
\hline $\begin{array}{c}\text { Net Recharge } \\
\text { of aquifer }\end{array}$ & 4 & $0-50.8$ & 1 & 4 \\
(mm/year) & $50.8-101.6$ & 3 & 12 \\
& $101.6-177.8$ & 6 & 24 \\
& & $>254.0$ & 8 & 32 \\
\hline
\end{tabular}




\section{Continued}

\begin{tabular}{|c|c|c|c|c|}
\hline \multirow{9}{*}{$\begin{array}{l}\text { Aquifer } \\
\text { media }\end{array}$} & \multirow{9}{*}{3} & Massive Shale & 2 & 6 \\
\hline & & Metamorphic/Igneous & 3 & 9 \\
\hline & & Weathered Metamorphic/Igneous & 4 & 12 \\
\hline & & $\begin{array}{l}\text { Thin Bedded Sandstone, } \\
\text { Limestone, Shale Sequences }\end{array}$ & 6 & 18 \\
\hline & & Massive Sandstone & 6 & 18 \\
\hline & & Massive Limestone & 6 & 18 \\
\hline & & Sand and Gravel & 8 & 24 \\
\hline & & Basalt & 9 & 27 \\
\hline & & Karst Limestone & 10 & 30 \\
\hline \multirow{11}{*}{ Soil media } & \multirow{11}{*}{2} & Thin or Absent & 10 & 20 \\
\hline & & Gravel & 10 & 20 \\
\hline & & Sand & 9 & 18 \\
\hline & & Peat & 8 & 16 \\
\hline & & Shrinking and/or Aggregated Clay & 7 & 14 \\
\hline & & Sandy Loam & 6 & 12 \\
\hline & & Loam & 5 & 10 \\
\hline & & Silty Loam & 4 & 8 \\
\hline & & Clay Loam & 3 & 6 \\
\hline & & Muck & 2 & 4 \\
\hline & & Nonshrinking and Nonaggregated clay & 1 & 2 \\
\hline \multirow{5}{*}{$\begin{array}{l}\text { Topography } \\
\text { (Slope) as (\%) }\end{array}$} & \multirow{5}{*}{1} & $0-2$ & 10 & 10 \\
\hline & & $2-6$ & 9 & 9 \\
\hline & & $6-12$ & 5 & 5 \\
\hline & & $12-18$ & 3 & 3 \\
\hline & & $>18$ & 1 & 1 \\
\hline \multirow{10}{*}{$\begin{array}{c}\text { Impact of } \\
\text { Vadose Zone }\end{array}$} & \multirow{10}{*}{5} & Silt/Clay & 1 & 5 \\
\hline & & Shale & 3 & 15 \\
\hline & & Limestone & 6 & 30 \\
\hline & & Sandstone & 6 & 30 \\
\hline & & Bedded Sandstone, Limestone, Shale & 6 & 30 \\
\hline & & Sand and Gravel with significant Silt and Clay & 6 & 30 \\
\hline & & Metamorphic/Igneous & 4 & 20 \\
\hline & & Sand and Gravel & 8 & 40 \\
\hline & & Basalt & 9 & 45 \\
\hline & & Karst Limestone & 10 & 50 \\
\hline \multirow{6}{*}{$\begin{array}{c}\text { Hydraulic } \\
\text { Conductivity } \\
\text { (m/day) }\end{array}$} & \multirow{6}{*}{3} & $0.0407-4.074$ & 1 & 3 \\
\hline & & $4.074-12.222$ & 2 & 6 \\
\hline & & $12.222-28.52$ & 4 & 12 \\
\hline & & $28.52-40.74$ & 6 & 18 \\
\hline & & $40.74-81.48$ & 8 & 24 \\
\hline & & $>81.48$ & 10 & 30 \\
\hline
\end{tabular}


model can be written as [21] [30] [34]:

$$
D_{I}=D_{r} * D_{w}+R_{r} * R_{w}+A_{r R} * A_{w}+S_{r} * S_{w}+T_{r} * T_{w}+I_{r} * I_{w}+C_{r} * C_{w}
$$

where $D, R, A, S, T, I$, and $C$ are the seven parameters, $\mathrm{r}$ and w refer to rating and weight values for the corresponding parameter.

After collecting all the required data to calculate the DRASTIC Index for a specific region, ArcMap10.3 of GIS-Software is needed to perform DRASTIC model on that region. The ArcMap10.3 gives the capabilities to construct a digital map (raster map) for each parameter of the seven parameters. The constructed maps work as layers for the same region. Then by using Raster Calculator Tool in Map Algebra Tool Box from Spatial Analyst Tools, an integrated map for the DRASTIC Index can be generated. The resultant map represents the Vulnerability index map of the region. From the literature [2] [20] [21] [31] [32] [33] [35] the vulnerability can be divided into seven classes depending on RASTIC index, these classes are summarized in Table 3. From Table 3, it can be seen that high DRASTIC index corresponds to high vulnerability, i.e. groundwater is easily affected by the contaminants.

\section{Results and Discussion}

After collecting and inputting all the required data to find the aquifer vulnerability for north Babylon region, Arc Map software was used to construct seven rated layers for that region representing seven parameters' maps, with one layer for each parameter. The resulting maps were two for each variable (before the rating and after the rating).

\subsection{Depth to Groundwater Table Map}

The results from the Arc Map program showed that the area of north Babylon is $2794.42 \mathrm{~km}^{2}$. The unrated map for the depth to the groundwater is shown in Figure 7 (a). The results indicate that most of the region (about $87 \%$ from the area) has a depth to groundwater ranging from 1.5 to $4.5 \mathrm{~m}$, and a small area (about 11\%) has groundwater depth with a range of 4.5 to $9.1 \mathrm{~m}$ and a very small area with depth to ground-

Table 3. Vulnerability classification.

\begin{tabular}{cc}
\hline Vulnerability class & DRASTIC Index \\
\hline No & $<61$ \\
Externally very low & $>61-80$ \\
Very Low & $>80-100$ \\
Low & $>100-120$ \\
Moderate & $>120-140$ \\
High moderate & $>140-160$ \\
High & $>160-180$ \\
Very high & $>180-200$ \\
Extremely very high & $>200$ \\
\hline
\end{tabular}




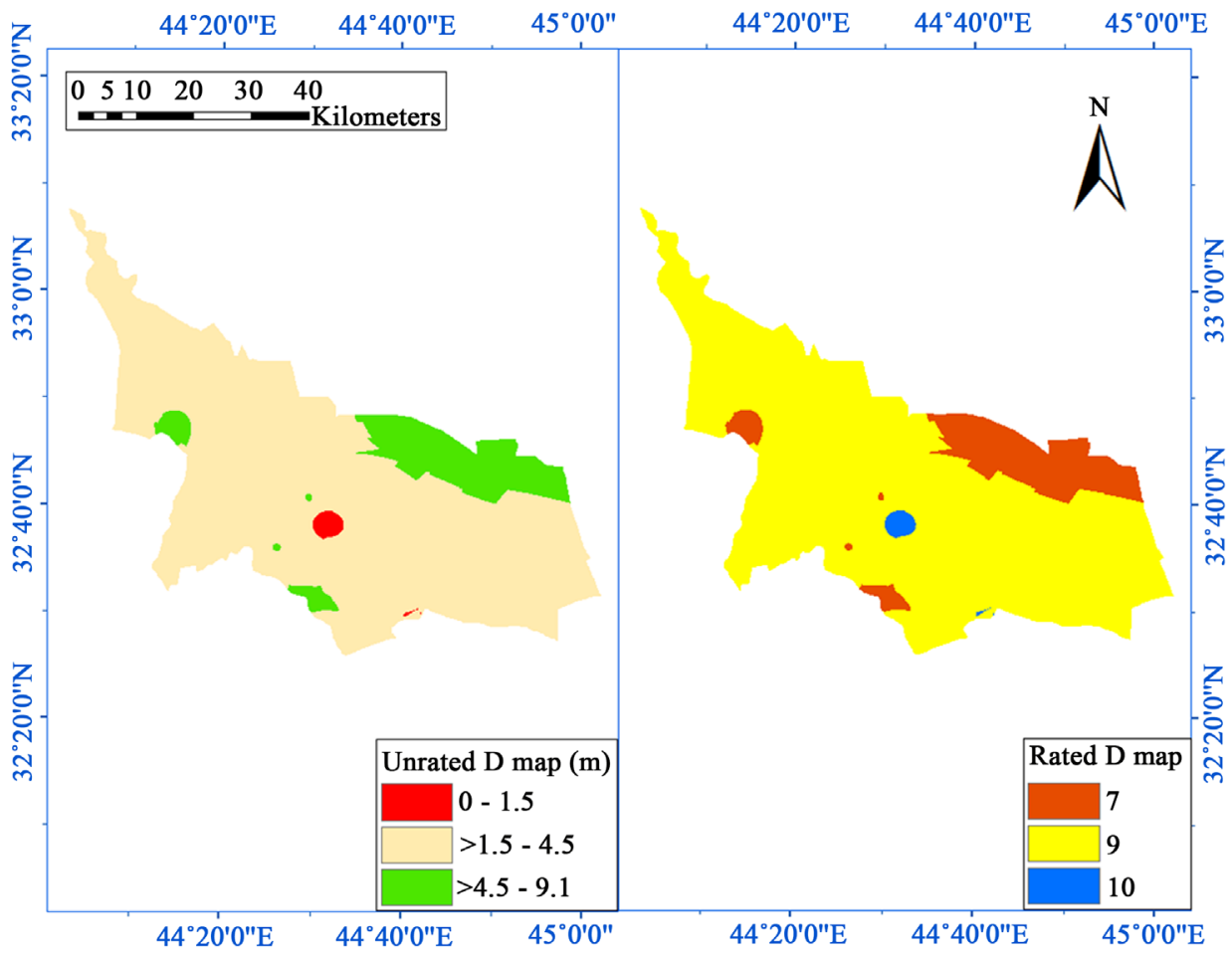

(a)

(b)

Figure 7. Depth to groundwater map ((a)-before the rating; (b)-after the rating).

water less than $1.5 \mathrm{~m}$. By using the Arc Map toolboxes the rated map for the depth to the groundwater was produced, and it is shown in Figure 7. The rated map (Figure $7(b))$ shows that there are three zones (depending on the rating) in the studied area which are 7, 9 and 10 zones.

\subsection{Net Recharge Map}

Figure 8(a) shows the unrated recharge map of the studied area. It is obvious from the map that all the area has a net recharge less than $50 \mathrm{~mm}$ /year. Consequently the rated map for the recharge is one zone map which has rating equal to 1 (Figure $8(\mathrm{~b})$ ).

\subsection{Aquifer Media Map}

The aquifer media for the studied area is from one type which is silty clay, as shown in Figure 9(a). Depending on that classification the rated map of the aquifer media has also one type rating which is 6 (Figure $9(\mathrm{~b})$ ).

\subsection{Soil Map}

According to Table 1 and the soil map for the study area (Figure 10(a)), there are three type of the soil rating in the studied area. These are clayey loam, silty loam and sandy loam. The results of ArcMap indicate that the area is covered by clayey loam soil (20\%), silty loam soil (74\%), and sandy loam soil (5\%). Consequently the rated map of the soil is shown in Figure 10(b). 


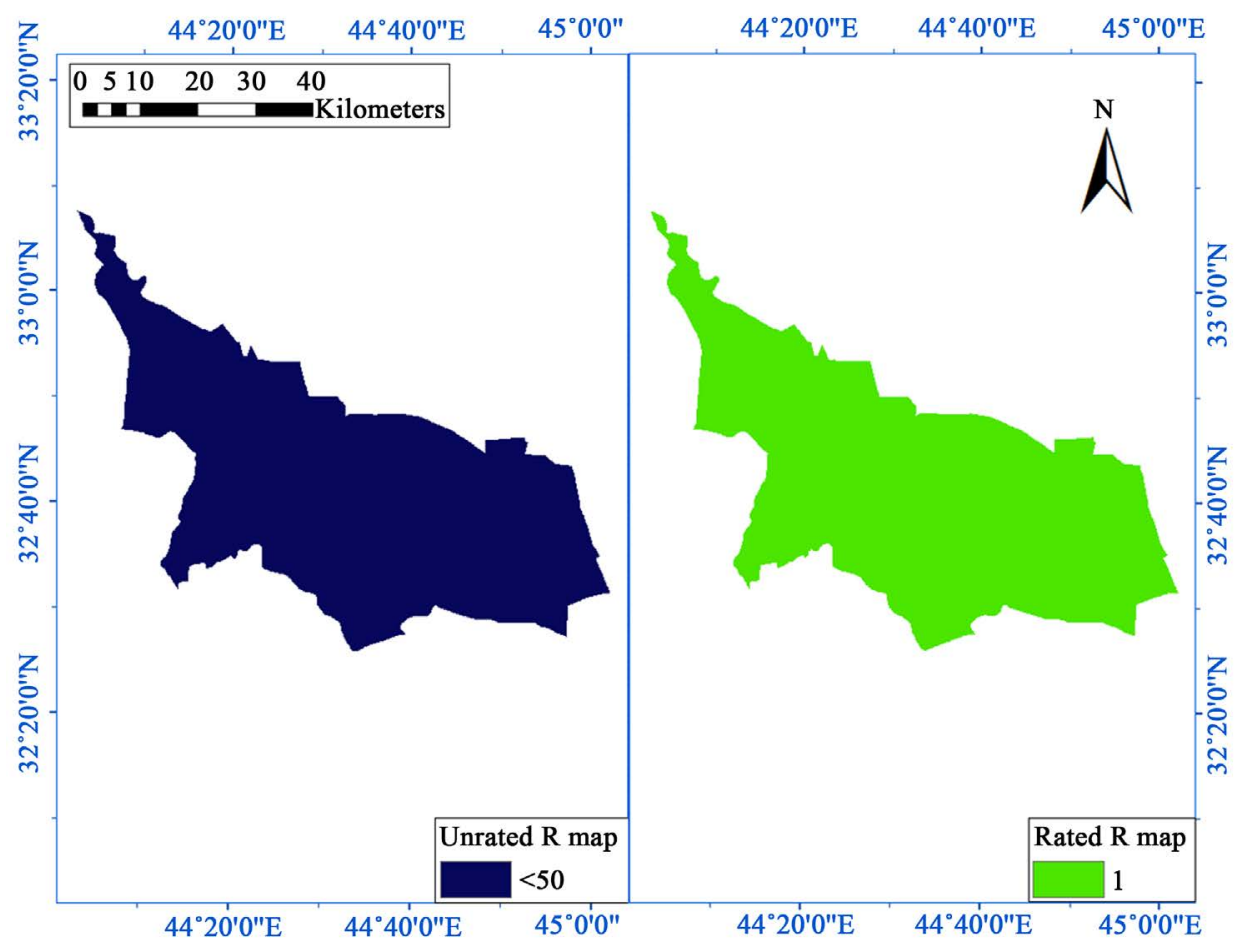

(a)

(b)

Figure 8. Recharge map ((a)-before the rating; (b)-after the rating).

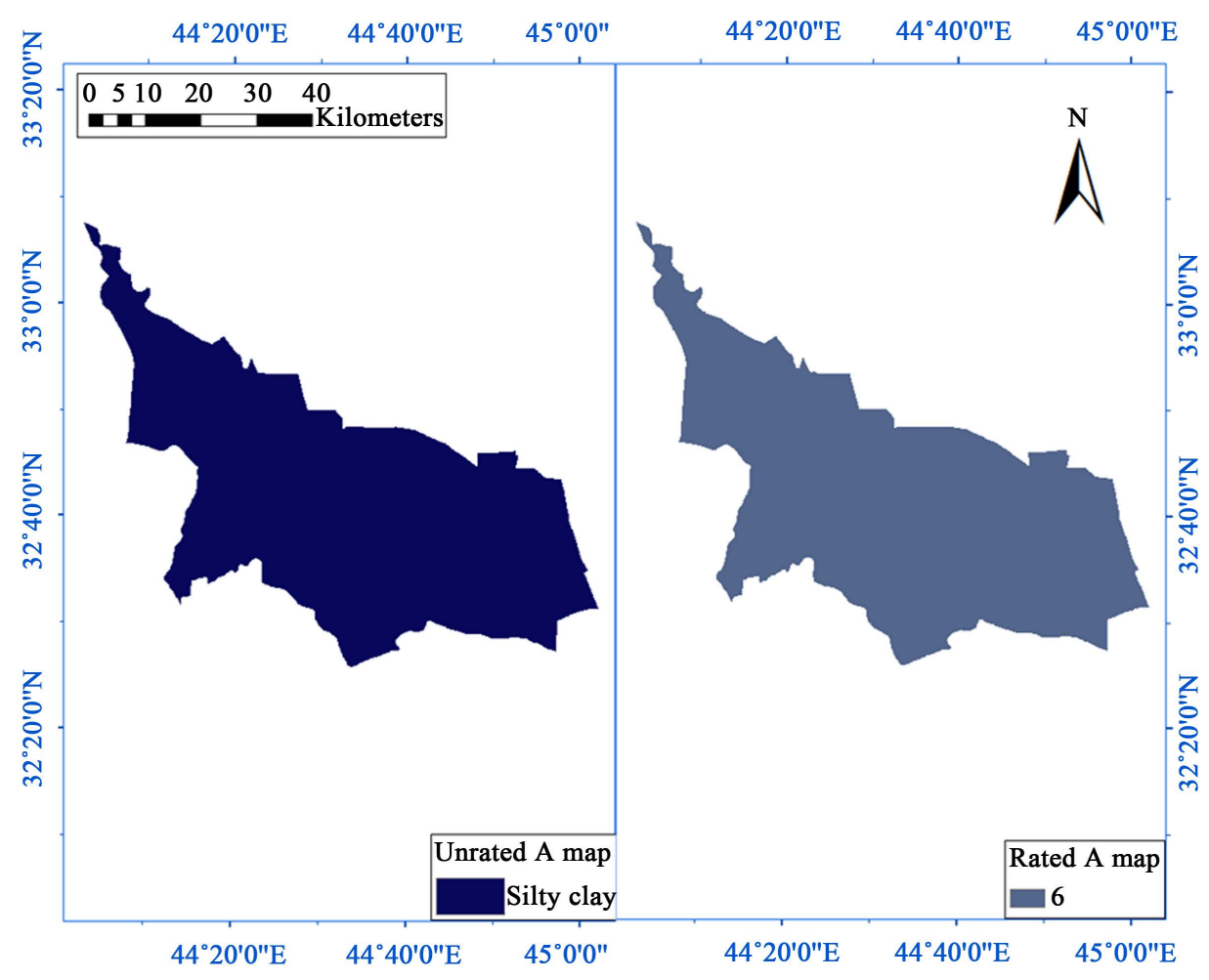

(a)

(b)

Figure 9. Aquifer media map ((a)-before the rating; (b)-after the rating). 


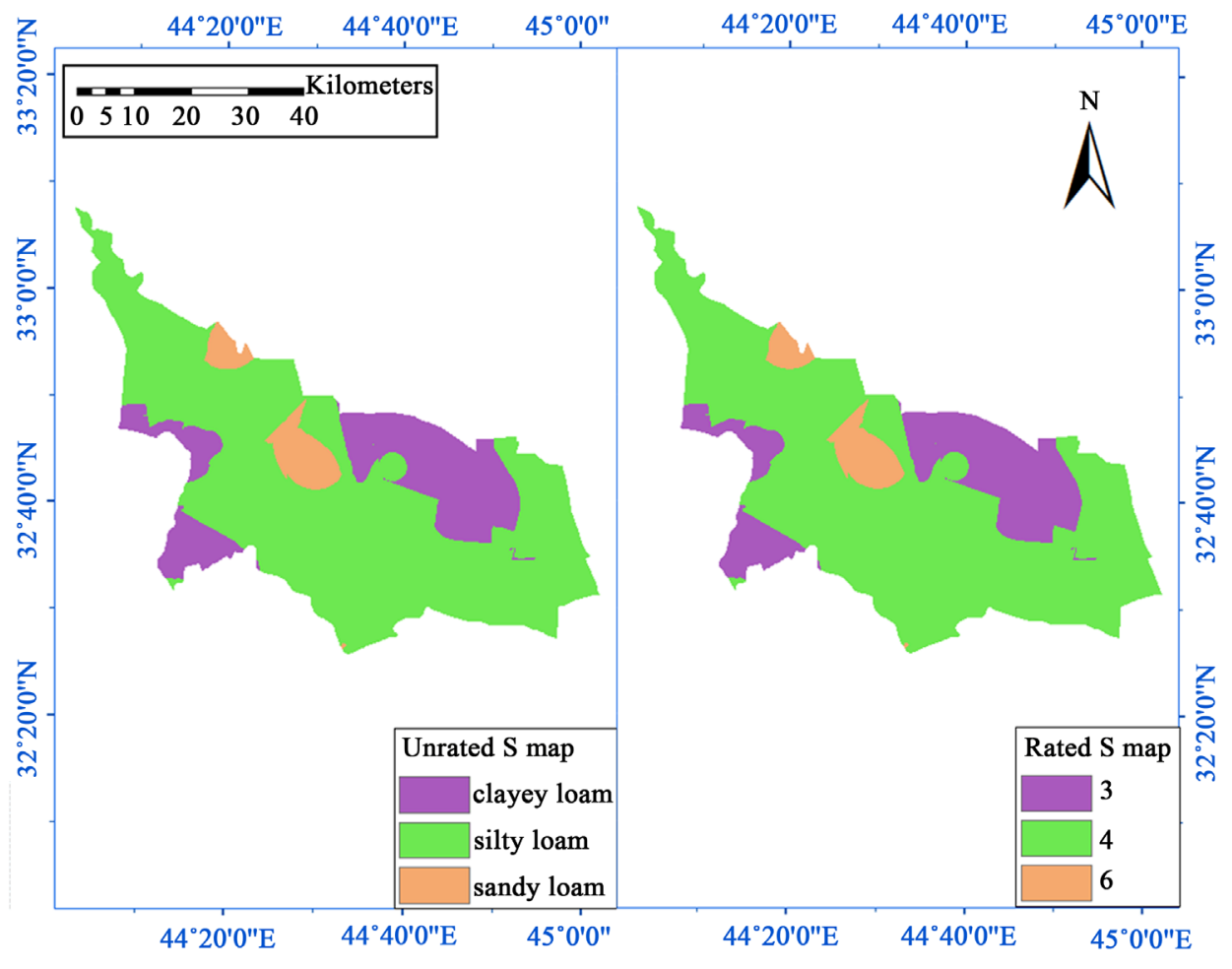

(a)

(b)

Figure 10. Soil map ((a)-before the rating; (b)-after the rating).

\subsection{Topographic Map (Slope Map)}

The topographic map can be produced by using the Digital Elevation Map (DEM) and the Arc toolboxes in ArcMap. The topographic map of the area is shown in Figure 11(a). The results show that most of the area (which is about 93\%) has a slope ranging between $0 \%$ and $2 \%$, while an area about $6.5 \%$ has a slope ranging from $2 \%$ to $6 \%$. Finally, a very small area $(0.026 \%)$ has a slope ranging between $6 \%$ and $10 \%$. According to the unrated map of the slope the topographic rated map can be drawn as in Figure 11(b), in which three types of zones can be distinguished according to the slope value which is 5,9 and 10 rated zones.

\subsection{Impact of Vadose Zone Map}

Figure 12(a) shows the unrated map of impact of vadose zone, in this figure the area is classified as one type, because the entire region has one type of vadose zone which is silty clay. Due to that classification the resultant rated map for impact of vadose zone in Figure 12(b) is also one type and has the rating 3 according to the classification in Table 2.

\subsection{Hydraulic Conductivity Map}

Figure 13(a) represents the unrated map of hydraulic conductivity, according to the results, the region is divided into 3 zones due to the difference in the hydraulic 


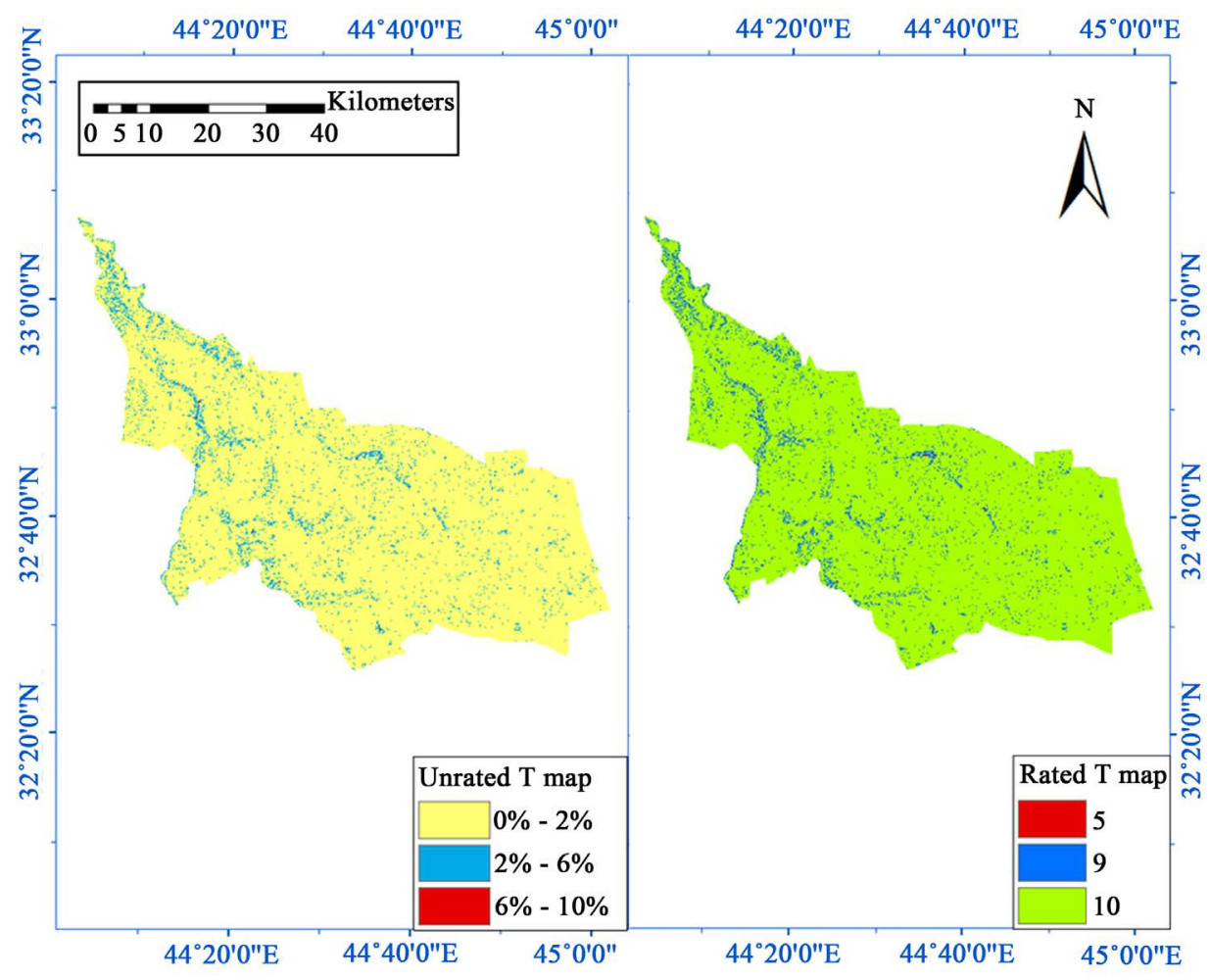

(a)

(b)

Figure 11. Topographic map ((a)-before the rating; (b)-after the rating).

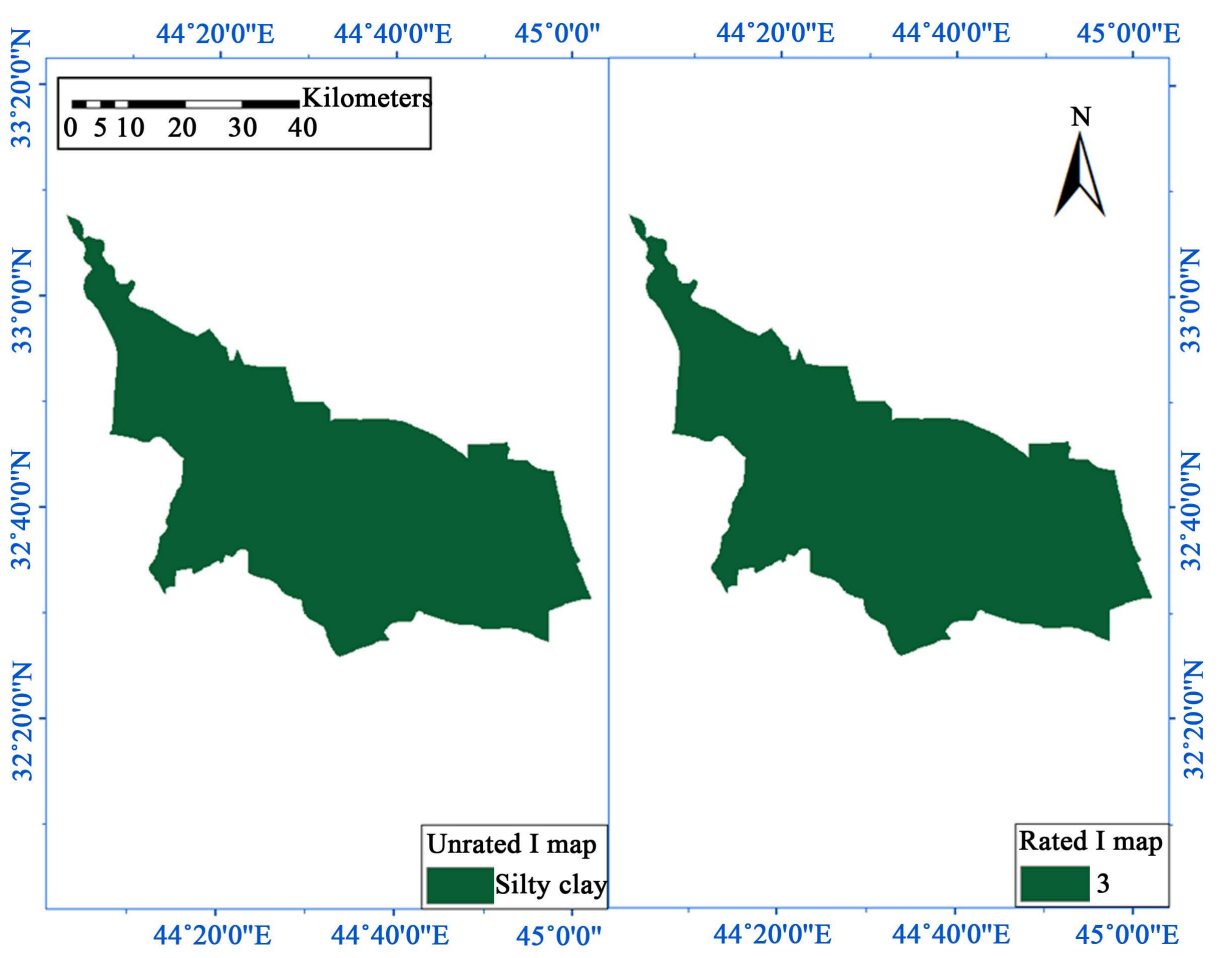

(a)

(b)

Figure 12. Impact of Vadose zone map ((a)-before the rating; (b)-after the rating). 


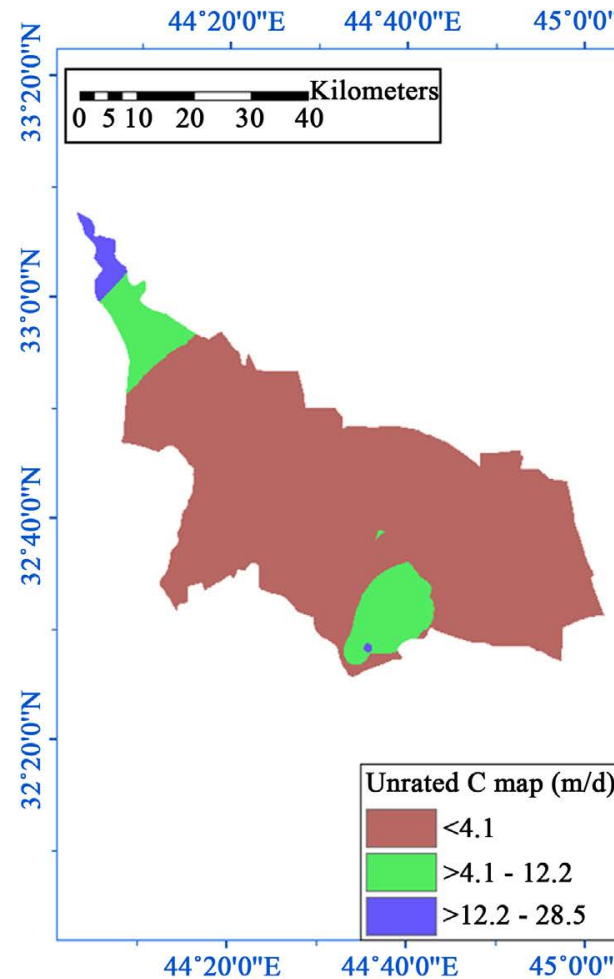

(a)

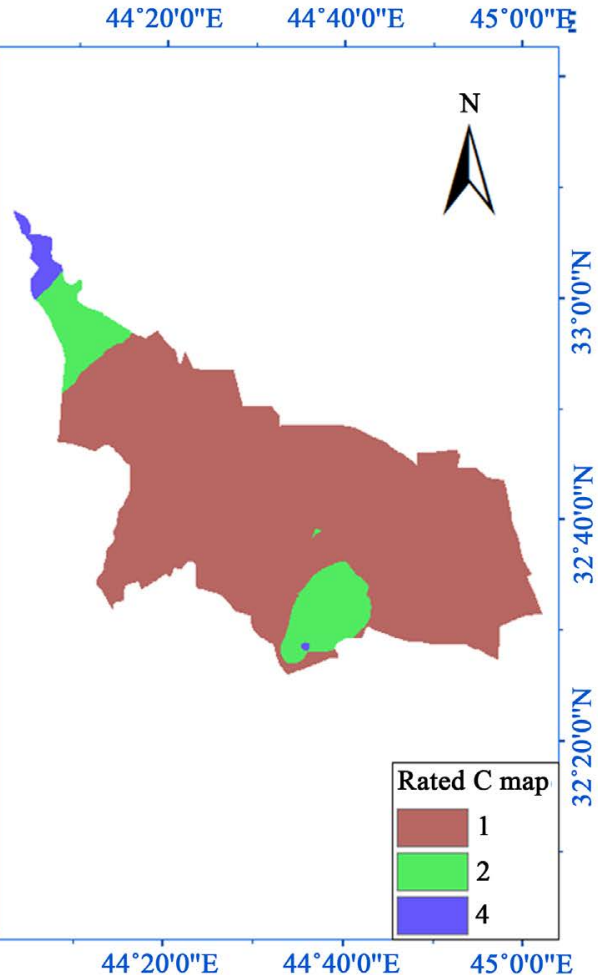

(b)

Figure 13. Hydraulic conductivity map ((a)-before the rating; (b)-after the rating).

conductivity of the aquifer. These zones are less than (4.1), (4.1 - 12.2) and (12.2 - 28.5) $\mathrm{m} / \mathrm{d}$ hydraulic conductivity. The results indicate that about $87 \%$ of the total area has hydraulic conductivity of less than $4.1 \mathrm{~m} / \mathrm{d}$. The remainder area (10\%) has hydraulic conductivity between 4.1 and $12.2 \mathrm{~m} / \mathrm{d}$, and about $1.5 \%$ has hydraulic conductivity between 12.2 and $28.5 \mathrm{~m} / \mathrm{d}$. Depending on these values the rated map of hydraulic conductivity was produced (Figure 13(b)). The resultant rated map shows three zones with rating 1,2 and 4 .

Table 4 shows some statistical values for the rated maps for all the seven parameters. The integrated vulnerability map is shown in Figure 14 . The map indicates that the region is divided into two zones according to the vulnerability. The first and second zones have vulnerability of $(86-100)$ and $(100-120)$ respectively. So the region in general is either has very low vulnerability or low vulnerability. This is due to the low rating values of the factors or because of the low weight values of these factors, especially recharge factor and impact of vadose zone, where they have high weight values but low rating values.

\section{Conclusion}

Due to water shortage problems in Iraq, it is expected that the demand of using groundwater resources will increase with time. Pollution of groundwater will create severe consequences. DRASTIC model had been applied to look at the vulnerability of 


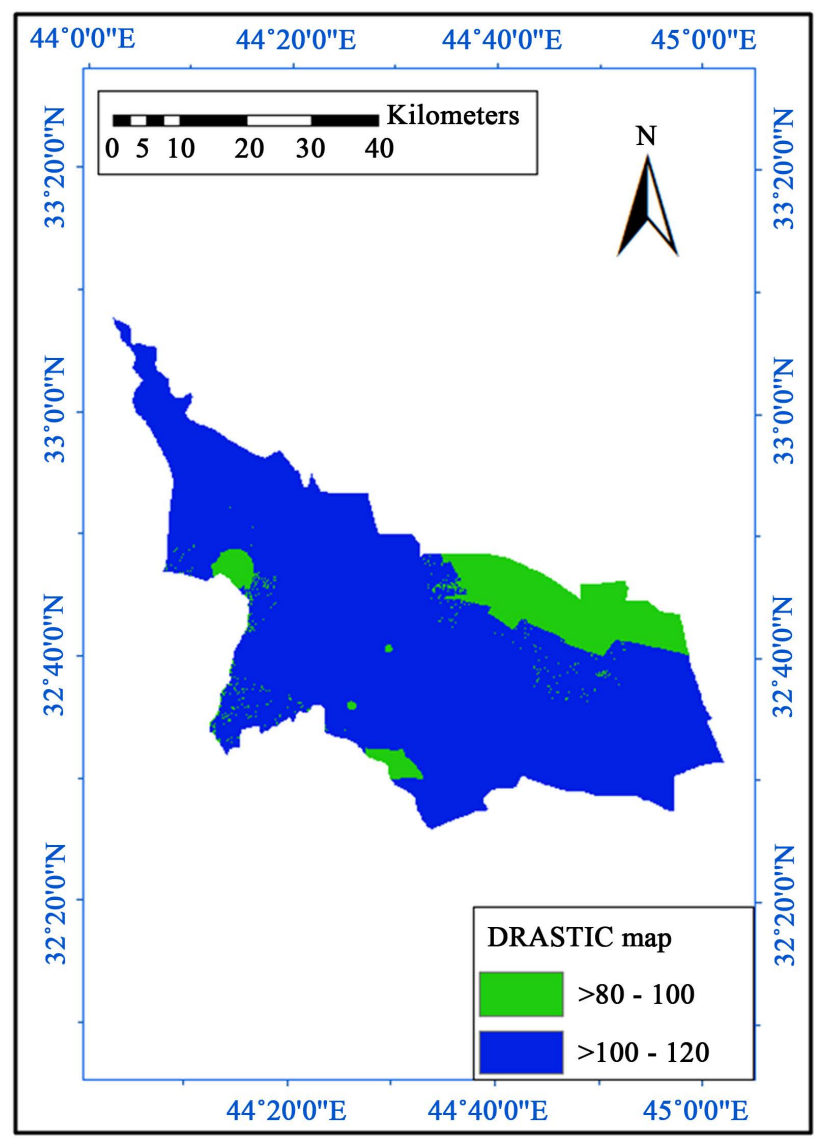

Figure 14. Vulnerability map.

Table 4. The statistical values for the rated maps.

\begin{tabular}{cccccc}
\hline map & Minimum value & Maximum value & Mean & $\begin{array}{c}\text { Standard } \\
\text { deviation }\end{array}$ & $\begin{array}{c}\text { Coefficient of } \\
\text { variation }\end{array}$ \\
\hline $\begin{array}{c}\text { Depth to groundwater } \\
\text { Net recharge }\end{array}$ & 7 & 10 & 8.7686 & 0.6570 & 0.2190 \\
Aquifer media & 1 & 1 & 1 & 0 & 0 \\
Soil & 3 & 6 & 6 & 0 & 0 \\
Topography & 5 & 6 & 4.0594 & 0.3397 & 0.1132 \\
Impact of Vadose zone & 3 & 10 & 9.9333 & 0.2596 & 0.0865 \\
Hydraulic conductivity & 1 & 3 & 3 & 0 & 0 \\
\hline
\end{tabular}

groundwater to pollution in the northern part of Babylon Governorate in Iraq. The results indicated that the area is divided into two regions according to its vulnerability. It either has very low vulnerability or low vulnerability. This leads to the possibility to utilize the groundwater in this region with small risks on its chemical or physical properties. It is noteworthy to mention that further checking is required due to the fact that the low rating values of the factors or because of the low weight values of these factors. 


\section{Acknowledgements}

The authors would like to thank the Iraqi Government for awarding a scholarship for the first author. Mr. Twana Abdullah, Mr. Maher Zainy and Mr. Ali Chabuk gratefully helped the authors.

\section{References}

[1] Villeneuve, J., Banton, O. and Lafrance, P. (1990) A Probabilistic Approach for the Groundwater Vulnerability to Contamination by Pesticides: The Vulpest Model. Ecological Modelling, 51, 47-58. https://doi.org/10.1016/0304-3800(90)90057-N

[2] Sinha, M.K., Verma, M.K., Ahmad, I., Baier, K. Jha, R. and Azzam, R. (2016) Assessment of Groundwater Vulnerability Using Modified DRASTIC Model in Kharun Basin, Chhattisgarh, India. Arabian Journal of Geosciences, 9, 1-22. https://doi.org/10.1007/s12517-015-2180-1

[3] Jamrah, A., Al-Futaisi, A., Rajmohan, N. and Al-Yaroubi, S. (2008) Assessment of Groundwater Vulnerability in the Coastal Region of Oman Using DRASTIC Index Method in GIS Environment. Environmental Monitoring and Assessment, 147, 125-138. https://doi.org/10.1007/s10661-007-0104-6

[4] Hussain, H.M., Al-Haidarey, M., Al-Ansari, N. and Knutsson, S. (2014) Evaluation and Mapping Groundwater Suitability for Irrigation Using GIS in Najaf Governorate, Iraq. Journal of Environmental Hydrology, 22, 1-16.

[5] Al-Ansari, N. (2013) Management of Water Resources in Iraq: Perspectives and Prognoses, Journal of Engineering, 5, 667-668. https://doi.org/10.4236/eng.2013.58080

[6] Al-Ansari, N. and Knutsson, S. (2011) Toward Prudent management of Water Resources in Iraq. Journal of Advanced Science and Engineering Research, 1, 53-67.

[7] Al-Ansari, N., Knutsson, S. and Ali, A. (2012) Restoring the Garden of Eden, Iraq. Journal of Earth Science and Geotechnical Engineering, 2, 53-88.

[8] Al-Ansari, N., Abdellatif, M., Ali, S. and Knutsson, S. (2014) Long Term Effect of Climate Change on Rainfall in Northwest Iraq. Central European Journal of Engineering, 4, 250-263. https://doi.org/10.2478/s13531-013-0151-4

[9] Al-Ansari, N., Abdellatif, M., Al-Khateeb, M. and Knutsson, S. (2014) Desertification and Future Rainfall Trends North Iraq. 8th Edition of the International Scientific Congress of GIS and Geospace Applications Geotunis, Tunis/Hammamet, 2-6 April 2014.

[10] Al-Ansari, N.A., Abdellatif, M., Zakaria, S., Mustafa, Y. and Knutsson, S. (2014) Future Prospects for Macro Rainwater Harvesting (RWH) Technique in North East Iraq. Journal of Water Resource and Protection, 6, 403-420. https://doi.org/10.4236/jwarp.2014.65041

[11] Al-Ansari, N.A., Abdellatif, M.,Ezeelden, M.,Ali, S. and Knutsson, S. (2014) Climate Change and Future Long Term Trends of Rainfall at North-Eastern Part of Iraq. Journal of Civil Engineering and Architecture, 8, 790-805.

[12] Al-Ansari, N.A., Ali, A. and Knutsson, S. (2014) Present Conditions and Future Challenges of Water Resources Problems in Iraq. Journal of Water Resources and Protection, 6, 1066-1098. https://doi.org/10.4236/jwarp.2014.612102

[13] Al-Ansari, N.A., Ali, A.A. and Knutsson, S. (2015) Iraq Water Resources Planning: Perspectives and Prognoses. 13 th International Conference on Civil and Construction Engineering, Jeddah, 26-27 January 2015, 2097-2108.

[14] Al-Ansari, N.A. (2016) Hydropolitics of the Tigris and Euphrates Basins. Engineering, 8, 140-172. https://doi.org/10.4236/eng.2016.83015 
[15] Baier, K., Schmitz, K.S., Azzam, R. and Strohschon, R. (2014) Management Tools for Sustainable Ground Water Protection in Mega Urban Areas-Small Scale Land Use and Ground Water Vulnerability Analyses in Guangzhou, China. International Journal of Environmental Research, 8, 249-262.

[16] Balakrishnan, P., Saleem, A. and Mallikarjun,N. (2011) Groundwater Quality Mapping Using Geographic Information System (GIS): A Case Study of Gulbarga City, Karnataka, India. African Journal of Environmental Science and Technology, 5, 1069-1084. https://doi.org/10.5897/AJEST11.134

[17] Barzegar, R., Moghaddam, A.A. and Baghban, H. (2016) A Supervised Committee Machine Artificial Intelligent for Improving DRASTIC Method to Assess Groundwater Contamination Risk: A Case Study from Tabriz Plain Aquifer, Iran. Stochastic Environmental Research and Risk Assessment, 30, 883-899. https://doi.org/10.1007/s00477-015-1088-3

[18] Vrba, J. and Zaporožec, A. (1994) Guidebook on Mapping Groundwater Vulnerability. (IAH)International Association of Hydrogeologists, IAH International Contributions to Hydrogeology, 16,131pp. Heise Publ., Hannover. http://trove.nla.gov.au/work/21381306? versionId=25583688

[19] Gogu, R.C. and Dassargues, A. (2000) Current Trends and Future Challenges in Groundwater Vulnerability Assessment Using Overlay and Index Methods. Environmental Geology, 39, 549-559.

https://orbi.ulg.ac.be/bitstream/2268/2562/2/2000\%20Current\%20and\%20future\%20trends \%20in\%20groundwater\%20vulnerability\%20assessment\%20GOGU\%26DASSARGUES.pdf https://doi.org/10.1007/s002540050466

[20] Hussain, H.M., Al-Ansari, N.A. and Knutsson S. (2015) Groundwater Pollution Potential in Part of the Western Desert, Iraq. Journal of Earth Sciences and Geotechnical Engineering, 5, 1-17.

[21] Abdullah, T.O., Ali, S.S., Al-Ansari, N.A. and Knutsson, S. (2015) Groundwater Vulnerability Mapping Using Lineament Density on Standard DRASTIC Model: Case Study in Halabja Saidsadiq Basin, Kurdistan Region, Iraq. Engineering, 7, 644-667. https://doi.org/10.4236/eng.2015.710057

[22] Al-Abadi, A.M. (2015) Modeling of Groundwater Productivity in Northeastern Wasit Governorate, Iraq Using Frequency Ratio and Shannon's Entropy Models. Applied Water Science, 1-18.

[23] Lindblom, J., Al-Ansari, N. and Al-Madhlom, Q. (2016) Possibilities of Reducing Energy Consumption by Optimization of Ground Source Heat Pump Systems in Babylon, Iraq. Engineering, 8, 130-139. https://doi.org/10.4236/eng.2016.83014

[24] Yacoub, S.Y. (2011) Geomorphology of the Mesopotamia Plain. Iraqi Bulletin of Geology and Mining, No. 4, 7-32.

[25] Yacoub, S.Y. (2011) Stratigraphy of the Mesopotamia Plain. Iraqi Bulletin of Geology and Mining, No. 4, 47-82.

[26] Al-Jiburi, H.K. and Al-Basrawi, N.H. (2011) Hydrogeology of the Mesopotamia Plain. Iraqi Bulletin of Geology and Mining, No. 4, 83-103.

[27] Sissakian, V.K., Ahad, A.D.A. and Hamid, A.T. (2011) Geological Hazards in Iraq. Classification and Geographical Distribution, 7, 1-28.

[28] Al-Adamat, R., Foster, I.D.L. and Baban, S.M.J. (2003) Groundwater Vulnerability and Risk Mapping for the Basaltic Aquifer of the Azraq Basin of Jordan Using GIS, Remote Sensing and DRASTIC. Applied Geography, 23, 303-324. http://www.hidro.ufcg.edu.br/twiki/pub/Disciplinas/GeotecnologiaAplicada/paper08.pdf https://doi.org/10.1016/j.apgeog.2003.08.007 
[29] Babiker, I.S., Mohamed, M.A.A., Hiyama, T. and Kato, K. (2005) A GIS-Based DRASTIC Model for Assessing Aquifer Vulnerability in Kakamigahara Heights, Gifu Prefecture, Central Japan. Science of the Total Environment, 345, 127-140.

http://users.clas.ufl.edu/jmjaeger/6932_gis/ex10/DRASTIC_GIS_2.pdf https://doi.org/10.1016/j.scitotenv.2004.11.005

[30] Aller, L., Lehr, J.H. and Petty, R. (1987) Drastic: A Standardized System to Evaluate Ground Water Pollution Potential Using Hydrogeologic Settings. National Water Well Association Worthington. http://rdn.bc.ca/cms/wpattachments/wpID3175atID5999.pdf

[31] Al-Zabet, T. (2002) Evaluation of Aquifer Vulnerability to Contamination Potential Using the DRASTIC Method. Environmental Geology, 43, 203-208.

http://download.springer.com/static/pdf/787/art\%253A10.1007\%252Fs00254-002-0645-5.p df?originUrl=http\%3A\%2F\%2Flink.springer.com\%2Farticle\%2F10.1007\%2Fs00254-002-06 45-5\&token $2=\exp =1482403658 \sim$ acl $=\% 2$ Fstatic $\% 2$ Fpdf $\% 2$ F787\%2Fart $\% 25253 \mathrm{~A} 10.1007 \% 25$ 252Fs00254-002-0645-5.pdf\%3ForiginUrl\%3Dhttp\%253A\%252F\%252Flink.springer.com \% 252Farticle\%252F10.1007\%252Fs00254-002-0645-5* hmac=ff50ce6fc8e1 ab37ca2434b6ddd 9acdb257a4f58584b942b54b756680ca6d45e https://doi.org/10.1007/s00254-002-0645-5

[32] Shrestha, S., Semkuyu, D.J. and Pandey, V.P. (2016) Assessment of Groundwater Vulnerability and Risk to Pollution in Kathmandu Valley, Nepal. Science of the Total Environment, 556, 23-35.

http://ac.els-cdn.com/S0048969716304478/1-s2.0-S0048969716304478-main.pdf?_tid=f8b1f 0f4-c837-11e6-b609-00000aab0f6c\&acdnat=1482405520_229c1139e407b0ba81d84ee76d8c8 $\underline{4 \mathrm{a} 0}$ https://doi.org/10.1016/j.scitotenv.2016.03.021

[33] Al-Rawabdeh, A.M., Al-Ansari, N.A., Al-Taani, A.A. and Knutsson, S. (2013) A GIS-Based Drastic Model for Assessing Aquifer Vulnerability in Amman-Zerqa Groundwater Basin, Jordan, 5, 490-504.

[34] Zhang, B., Li, G., Cheng, P., Yeh, T.C. and Hong, M. (2016) Landfill Risk Assessment on Groundwater Based on Vulnerability and Pollution Index. Water Resources Management, 30, 1465-1480. http://link.springer.com/article/10.1007/s11269-016-1233-x https://doi.org/10.1007/s11269-016-1233-x

[35] Al-Rawabdeh, A.M., Al-Ansari, N., Knutsson, S., Al-Taani, A. and Al-Khateeb, F. (2014) Modeling the Risk of Groundwater Contamination Using Modified DRASTIC and GIS in Amman-Zerqa Basin, Jordan. Central European Journal of Engineering, 4, 264-280. http://link.springer.com/article/10.2478/s13531-013-0163-0 https://doi.org/10.2478/s13531-013-0163-0 
Submit or recommend next manuscript to SCIRP and we will provide best service for you:

Accepting pre-submission inquiries through Email, Facebook, LinkedIn, Twitter, etc. A wide selection of journals (inclusive of 9 subjects, more than 200 journals)

Providing 24-hour high-quality service

User-friendly online submission system

Fair and swift peer-review system

Efficient typesetting and proofreading procedure

Display of the result of downloads and visits, as well as the number of cited articles

Maximum dissemination of your research work

Submit your manuscript at: http://papersubmission.scirp.org/

Or contact eng@scirp.org 